\title{
The Urban Centers Development: An Analysis of Different Cultural Influences with an Impact on Urban Changes Based on the Example of Berlin
}

\author{
Vývoj městských center: Analýza rozdílných \\ kulturních vlivů s dopadem na změnu \\ urbánního prostředí na príkladu Berlína
}

\author{
Monika Moggert \\ Ústav památkové péče, Fakulta architektury, Vysoké učení technické v Brně \\ školitel: doc. Ing. arch. Ivo Boháč, Ph.D.
}

\begin{abstract}
The current topic of this paper evaluates the changes in the public urban space, depending on the current demographic transformation of Europe. It focuses on the life of immigrant communities living in the districts of Berlin - Neukölln and Kreuzberg - and their impact on the urban environment. It shows the issue of an inhumane scale in contrast to small-scale sites. Furthermore, it provides an example of the likely development of these districts, evaluating their benefits and negative aspects. At the same time, it offers the opportunity to use foreign experiences for modern city planning.
\end{abstract}

KEYWORDS: cultural influences; urban change; centers development; Berlin; Neukölln; Kreuzberg

\begin{abstract}
ABSTRAKT: Aktuální téma hodnotí změny veřejného městského prostoru v závislosti na současné demografické přeměně Evropy. Soustředí se na život přistěhovaleckých komunit v berlínských čtvrtích Neukölln a Kreuzberg a jejich vlivy na urbánní prostředí. Poukazuje na problematiku nelidského měřítka některých městských částí v kontrastu s drobným měŕítkem vytipovaných míst. Poskytuje př́klad pravděpodobného vývoje těchto lokalit, hodnotí jejich přínos a negativa. Zároveň přináší možnost využití zahraničních zkušeností pro novodobé koncipování měst.
\end{abstract}

KLÍČOVÁ SLOVA: kulturní vlivy; urbánní změny; vývoj center; Berlín; Neukölln; Kreuzberg 


\section{Úvod}

Evropská města dnes řeši problematiku současné přistěhovalecké vlny, která přináší spoustu problémů, otázek, ale i nové vize. Nutno říci, že z hlediska historického vývoje se nejedná o situaci ojedinělou, ale opakující se. Ve velkých evropských aglomeracích, jako je Berlín, Vídeň, Pařiž apod., jsou patrné již etablované multikulturní oblasti, které vytváří specifickou tvář města a které mohou být použity jako prríklad pro nové koncepce evropských měst.

Tato práce přihlíží k otázkám současných demografických změn v Evropě. Nezabývá se jimi v detailním kontextu z pohledu změn dočasných, nastiňuje však pravděpodobný vývoj a vlivy trvalého charakteru.

\section{Stručná historie vývoje města}

Berlín je město s bohatou historií, jehož počátky se datují okolo roku 600 , kdy na jeho území žili Slované. Dramatická změna ve struktuře obyvatelstva nastala již ve 12. stol., tehdy dochášlo k porážce Slovanů Germány.

Až do 19. stol. zaznamenává město neustálý růst. Kolem města vznikají nová osídlení, jež se později připojují, a 1. ř́jna 1920 vzniká aglomerace Velký Berlín, jež v dané chvíli čítá 3,8 mil. obyvatel (pro porovnání nyní: 3,7 mil. obyvatel).

V průběhu 2. sv. války byly kompletně zničeny centrální části města a s nimi i rostlá kompozice městské struktury. Byla potřeba dostavba města, a především obnova dopravní infrastruktury.

Neblahým dopadem 2. sv. války je také rozdělení Německa 12. května 1949 na Spolkovou republiku Německo (SRN) a Německou demokratickou republiku (NDR), a tedy i rozdělení města na Západní Berlín a Východní Berlín.

Západní část Berlína řeši problém nedostatku pracovních sil a využívá pracovníků hlavně z Turecka, bývalé Jugoslávie, Itálie, Řecka a Španělska. V roce 1968 žilo v SRN 1,9 milionu přistěhovalců. [1]

Roku 1989 padla Berlínská zed'. Nastává tak otázka, co s územím v místě po dělící zdi, které protíná celé město. Řeší se možnosti spojení obou částí. Obnovuje se dopravní propojení.

Z dnešního pohledu je Berlín město, kde probíhá neustále stavební vývoj; je inspirací 
pro celou Evropu v rámci trendu trvale udržitelného urbanismu a z hlediska demografického přeměňování evropského prostředí. Je centrem současné architektury. Je tedy logicky klíčovým městem pro ukázku řešení problémů aktuální tematiky.

\section{Současná demografická situace a kulturní vlivy}

Demografické změny jsou procesy, jež ovlivňují nejen ekonomické, geografické, sociální a demografické struktury, ale i změny v urbánním prostředí. Jsou určitým komponentem urbanizačních procesů a zvyšování územní koncentrace obyvatelstva. [2]

V rámci přirozeného pohybu, tak jako u většiny vyspělých zemí, v Berlíně pozorujeme přirozený úbytek obyvatelstva, který můžeme označit dnes zažitým pojmem „stárnutí populace“ a jenž představuje velkou ekonomickou zátěž pro město.

Berlín a celé Německo však v současnosti řeší hlavně otázku mezikontinentálního pohybu obyvatelstva - migračního nárůstu obyvatel ze Sýrie i ze států Blízkého východu a Afriky. Plánem Německa je pokusit se integrovat tyto obyvatele a tím eliminovat již zmiňovaný pokles počtu obyvatel.

\section{Etnická struktura obyvatelstva}

Etnická struktura obyvatelstva je více než rozmanitá. V Berlíně žije přes 180 etnických skupin v podílu 19,2 \% na celkovém počtu 3711930 obyvatel. Z Evropy pochází 463 tis. přistěhovalců, přičemž nejpočetnější etnické skupiny se hlásí k národnosti turecké (98 tis. obyvatel), polské (57 tis. obyvatel), italské a bulharské (29 tis. obyvatel), ruské (24 tis. obyvatel) a rumunské (21 tis. obyvatel).

Z Asie pochází 148 tis. prristěhovalců (z toho 70 tisíc je z Blízkého východu), z Ameriky 42 tisíc a z Afriky 31 tisíc. [3]

\section{Kulturní vlivy a městský prostor}

Ačkoli je v Berlíně velký počet etnických skupin, nejpočetnější skupinou zasahující do urbánního prostoru a mající na něj viditelný vliv jsou obyvatelé hlásící se k turecké národnosti. Ti zde žijí již ve třetí a čtvrté generaci a vybudovali si zde zázemí blízké jejich životnímu stylu. Ve městě, které působí někdy až studeným dojmem a v němž je veřejný prostor skoro neměnný a měřítko zástavby nelidské, etablují do struktury onu neplánovanost a pozitivní chaos. Inspirací je jim prostředí, odkud přišli, a můžeme i říci, že se zde projevuje kulturní vliv Blízkého východu. Ten je patrný především na drobném měřítku a specifickém charakteru městské struktury. Do ní se rovněž promítá mentalita obyvatel, která je oproti německé vřelejší a komunikativnější. I tyto 
aspekty jsou vpisovány do podoby městského prostoru, když v lokalitách Kreuzberg a Neukölln můžeme spatřit množství malých obchodů, tržišt' (dodávajících ulicím život), kaváren a typického rychlého občerstvení. Je zde dobře patrná symbióza lidí různých národností, život v těchto lokalitách je provázen směsicí světových jazyků.

Kulturní odlišnosti přináší do lokality samozřejmě i určité problémy - na jedné straně např̀ přemíru cizinců ve školách, na straně druhé drogové dealery v ulicích apod.

Živelností a svérázným způsobem života získaly čtvrtě na atraktivitě. Jsou známé a populární jak pro řadu studentů, mladých lidí a zde žijících umělců, tak i pro turisty, tedy sociální skupiny vyhledávající například bujarý noční život. Rostoucí kreativita přináší lokalitám tvořivé nápady, jež zde můžeme spatřit v podobě urbánního zahradnictví - malých zahrádek v uličním prostoru (např. okolo stromů), které vytváŕí sami jeho obyvatelé -, maleb a různých dalších uměleckých projevů.

Čtvrtě jsou místy setkávání, a to jak z urbanistického hlediska - náměstí, obchodní ulice, parky, tak i z hlediska sociálního - občané čtvrtí mají přirozenou touhu pomáhat si a společně budovat příjemná a prospěšná prostředí, např. centra vzdělávání a setkávání s možností sdílet předměty a zkušenosti, chư podílet se na vytváření městského mobiliáře apod.

\section{Situace čtvrtí Neukölln a Kreuzberg}

Kreuzberg a Neukölln vznikly na místě bývalých vesnic, založených okolo 13. stol. Historickou podstatu vesnic můžeme spatřit i dnes ve struktuře městských částí. Dnešní ráz však definuje převážně období 19. stol. Pokud sledujeme otázku přistěhovalectví, je zajímavé, že v 18. stol. bylo například umožněno vyhnaným českým husitům usídlit se v lokalitě Neukölln. Po konci druhé světové války a rozdělení Berlína území připadla západní části Berlína. V lokalitách bydleli i přistěhovalečtí pracovníci (především turecké národnosti), kteří zde dnes tvoří třetinu místních obyvatel.

Čtvrtě jsou ve velkém kontrastu s novými developerskými projekty a centrem Berlína (Alexanderplatz a přilehlé okolí), které se ztrácí v nelidském měřítku rozlehlých náměstí a blokové zástavby a vysokém stupni dopravní vytíženosti. Fasády domů jsou navrženy převážně s horizontálními liniemi, cesty pro pěši jsou příliš dlouhé, náplň města se zdá být roztř́ǐstěná. Funkce střetávání se je zde nahrazena pouze funkcí nákupní, a to převážně v nákupních centrech. Parter domů a jemu přilehlé prostory tedy odumírají a život se odehrává někde uvnitř budov.

$\mathrm{V}$ současné době je $\mathrm{v}$ lokalitách velice diskutovaným tématem pojem gentrifikace. Zajímavé a v lidském měřítku komponované lokality Neukölln a Kreuzberg jsou „kul- 
tivovány“. Hlavním důvodem je prodej městských bytů v období finanční krize města, kdy jich senát prodal více než polovinu a z původních 650 tisíc (v roce 1990) bylo ponecháno pouze 258 tisíc (v roce 2010). Tím se v lokalitách objevily ve velké míře komerční pronájmy, které jsou v důsledku dále spojovány s vydíráním a kriminalitou $\mathrm{v}$ rámci ochrany nájemného. Skutečnost je taková, že dochází ke zvyšování nájemného, úpravě domů a jejich parterů pro komerci ve vyšších cenových kategoriích a s tím i souvisejícímu odlivu v současnosti zde žijících kreativních obyvatel vytvářejících toto specifické prostředí. Pokud se z Berlína vytratí onen genius loci, město pozbude důvodu, proč je natolik vyhledávaným kulturním centrem. Hrozí změna spádovosti území a přesun center na jiné místo, přesněji řečeno dál od hlavního centra města. $S$ přihlédnutím k současným trendům je vysoká pravděpodobnost, že v budoucnu nastane úpadek center etnických komunit s veškerou jejich živelností, jedinečností. Dojde ke zvětšení měřítka urbanistické struktury a tím i znehodnocení celé kompozice.

\section{Závěr}

Málokteré město prošlo tak pestrou škálou událostí, politických zvratů, ničení, obnov a s tím souvisejících pokusů zasáhnout do jeho vývoje tak, aby byl zanechán podpis př́slušné etapy dějin, mocenských ambicí, prosazení vizí apod. Prostor pro vznik jedinečné městské struktury byl uvolněn i neskutečným válečným narušením přirozeného vývoje za 2 . sv. války. To sice uvolnilo plochy pro nové vize, ale město dnes těžko nalézá cestu k pohodě prostředí, cestu ze stereotypu a neosobnosti novodobé architektury.

Na druhou stranu v oblastech, kde nedošlo k výraznému narušení kontinuity vývoje a jež jsou osídleny z velké části přistěhovaleckými komunitami, je přirozeně vytvářeno prostředí plné života v celé jeho pestrosti, místo v jeho lidském měřítku. Nejedná se však o prostředí sterilní, tudíž s sebou přináší i problematiku každodenního života. Lidé jsou zde zvyklí více komunikovat a navzájem spolupracovat. Pro ostatní berlínské čtvrtě a evropské aglomerace by tyto lokality mohly být inspirativním místem snahy o zachování specifického prostředí, snahy o zachování genia loci. 


\section{Použité zdroje}

[1] Parlament, Landesregierung und Bezirke. Berlin. [cit. 02. 04. 2018]. Dostupné z: https://www.berlin.de/berlin-im-ueberblick/landespolitik/parlament-landesregierung-und-bezirke/

[2] FALTRUSOVÁ Gabriela. Mezinárodní migrace z Turecka do Spolkové republiky Německo. Brno, 2014. Bakalářská práce. Mendelova univerzita v Brně. Fakulta regionálního rozvoje a mezinárodních studií. Vedoucí práce Ing. Milan Palát, Ph.D.

[3] TOUŠEK Václav, KUNC Josef, VYSTOUPIL Jiří aj. Ekonomická a sociální geografie. Brno: Vydavatelství a nakladatelství Aleš Čeněk, s.r.o., 2008. ISBN 978-80-7380-114-4.

[4] Statistischer Bericht:AI5 - hj 2/17, Einwohnerinnen und Einwohner im Land Berlin am 31. Dezember 2017. Amt für Statistik Berlin-Brandenburg, 2018. [cit. 29. 04. 2018] Dostupné z: https://www.statistik-berlin-brandenburg.de/publikationen/Stat_Berichte/2018/SB_A01-05-00_2017h02_BE.pdf

[5] Geschichte der Berliner Bezirke. Berlin. [cit. 26. 02. 2018]. Dostupné z: https:// www.berlin.de/geschichte/geschichte-der-berliner-bezirke/

BUFFET, Cyril. Berlín. Praha: Nakladatelství Lidové noviny, 1999. ISBN 80-7106-314-2.

ULRICH Horst, PRELL Uwe, LUUK Ernst. Berlin Handbuch.:das Lexikon der Bundeshauptstadt, Besiedlung des Berliner Raums. Berlin: FAB Verlag, 1992. ISBN 3-927551-27-9.

Geschichte. Berlin. [cit. 27. 03. 2018]. Dostupné z: https://www.berlin.de/berlin-im-ueberblick/geschichte/ 